Crop Breeding and Applied Biotechnology 12: 104-110, 2012

Brazilian Society of Plant Breeding. Printed in Brazil

\title{
ARTICLE
}

\section{Genetic diversity of Cuban pineapple germplasm assessed by AFLP Markers}

Ermis Yanes Paz ${ }^{1 *}$, Katia Gil², Laureano Rebolledo ${ }^{3}$, Andrés Rebolledo ${ }^{3}$, Daniel Uriza ${ }^{3}$, Octavio Martínez ${ }^{2}$, Miriam Isidrón ${ }^{1}$, Leyanes Díaz ${ }^{1}$ José Carlos Lorenzo ${ }^{1}$ and June Simpson²

Received 15 February 2011

Accepted 30 June 2011

\begin{abstract}
The Cuban pineapple germplasm collection represents the genetic diversity of pineapple cultivated in that country and includes other important genotypes obtained from the germplasm collections in Brazil and Martinique. The collection has previously been characterized with morphological descriptors but a molecular characterization has been lacking. With this aim, 56 six genotypes of A. comosus and one of Bromelia pinguin were analyzed with a total of 191 AFLP markers. A dendrogram that represents the genetic relationships between these samples based on the AFLP results showed a low level of diversity in the Cuban pineapple collection. All Ananas comosus accessions, being the majority obtained from farmers in different regions in Cuba, are grouped at distances lower than 0.20. Molecular characterization was in line with morphological characterization. These results are useful for breeding and conservation purposes.
\end{abstract}

Key words: molecular markers, accessions, Ananas.

\section{INTRODUCTION}

Pineapple (Ananas comosus (L) Merr) is an important crop for many countries in Central and South America as well as in the Asia-Pacific region. Most of the pineapple production is based on a few leading cultivars, such as Smooth Cayenne and MD2. In Cuba, Spanish cultivars are predominant.

Pineapple germplasm is maintained in several collections around the world. The most important are the collections maintained by EMBRAPA/CNPMF, in Cruz das Almas, Brazil, by CIRAD-FLHOR, in Martinique, and the USDA collection, in Hawaii. These collections have been partially characterized with morphological descriptors (Leal et al. 1986, Duval and Coppens d'Eeckenbrugge 1993, Ferreira and Cabral 1993, Duval et al. 1996). Cuba maintains a small but still important collection, since it represents the genetic diversity of the cultivated pineapple in that country. Most of the genotypes in the Cuban pineapple germplasm collection at the Bioplants Center (Ciego de Ávila, Cuba) have been obtained from farmers or through exchanges with other collections (Isidrón et al. 2003).
Aradhya et al. (1994) and De Wald et al. (1992) have previously used isozyme polymorphism in the genus Ananas to clarify taxonomical aspects. However, the scope of these studies is limited due to the low number of markers. Later, Duval et al. (2001) and Duval et al. (2003) used RFLP markers and chloroplast genotypes or genoma to study genetic diversity in Ananas. Three hundred and one accessions including all Ananas species and the related species Pseudoananas sagenarius were tested. This technique revealed a higher level of polymorphism since $41 \%$ of the probes were polymorphic. Based on these studies, Coppens d'Eeckenbrugge and Leal (2002) have proposed a simplification for the pineapple classification. In this new classification, the seven Ananas species proposed by Smith and Downs (1979) are downgraded to the level of five botanical varieties of A. comosus.

AFLP markers (Vos et al. 1995) have also been widely used to study diversity in several species such as Arabidopsis (Breyne et al. 1999), coffee (Coulibaly et al. 2003), Rubus (Marulanda et al. 2007) and Jatropha curcas (Santos et al. 2010). The technique has also been employed to identify varieties in pineapple (Leal et al.

\footnotetext{
${ }^{1}$ Universidad de Ciego de Avila, Centro de Bioplantas, Carretera a Morón, km 9, CP 069450, Ciego de Ávila, Cuba. *E-mail: eyanes@bioplantas.cu

2 CINVESTAV, Departamento de Ingeniería Genética, Unidad Irapuato, Apdo. Postal 629, Irapuato, Guanajuato, Mexico

3 INIFAP, Campo Experimental Papaloapan, Veracruz, Mexico
}

Crop Breeding and Applied Biotechnology 12: 104-110, 2012 
EY Paz et al.

1986) and carry out classical genetic mapping studies (Carlier et al. 2004). Kato et al. (2004), Paz et al. (2005) and Tapia Campos et al. (2005) proved its suitability for germplasm evaluation.

In this work, AFLP markers were used to assess the genetic diversity of the Cuban pineapple germplasm collection that represents both commercially cultivated material grown in Cuba and germplasm used in ongoing breeding programs.

\section{MATERIALS AND METHODS}

Fifty-six genotypes, including fifty-five genotypes of Ananas comosus and one of Bromelia pinguin, belonging to the Cuban National Pineapple Germplasm Collection at the Bioplants Centre (Ciego de Ávila, Cuba), were analyzed (Table 1). The names used in this article correspond with common names used locally. The species were indicated according to the last classification by Coppens d'Eeckenbrugge and Leal (2002).

Table 1. Pineapple cultivars and relatives analyzed in the study

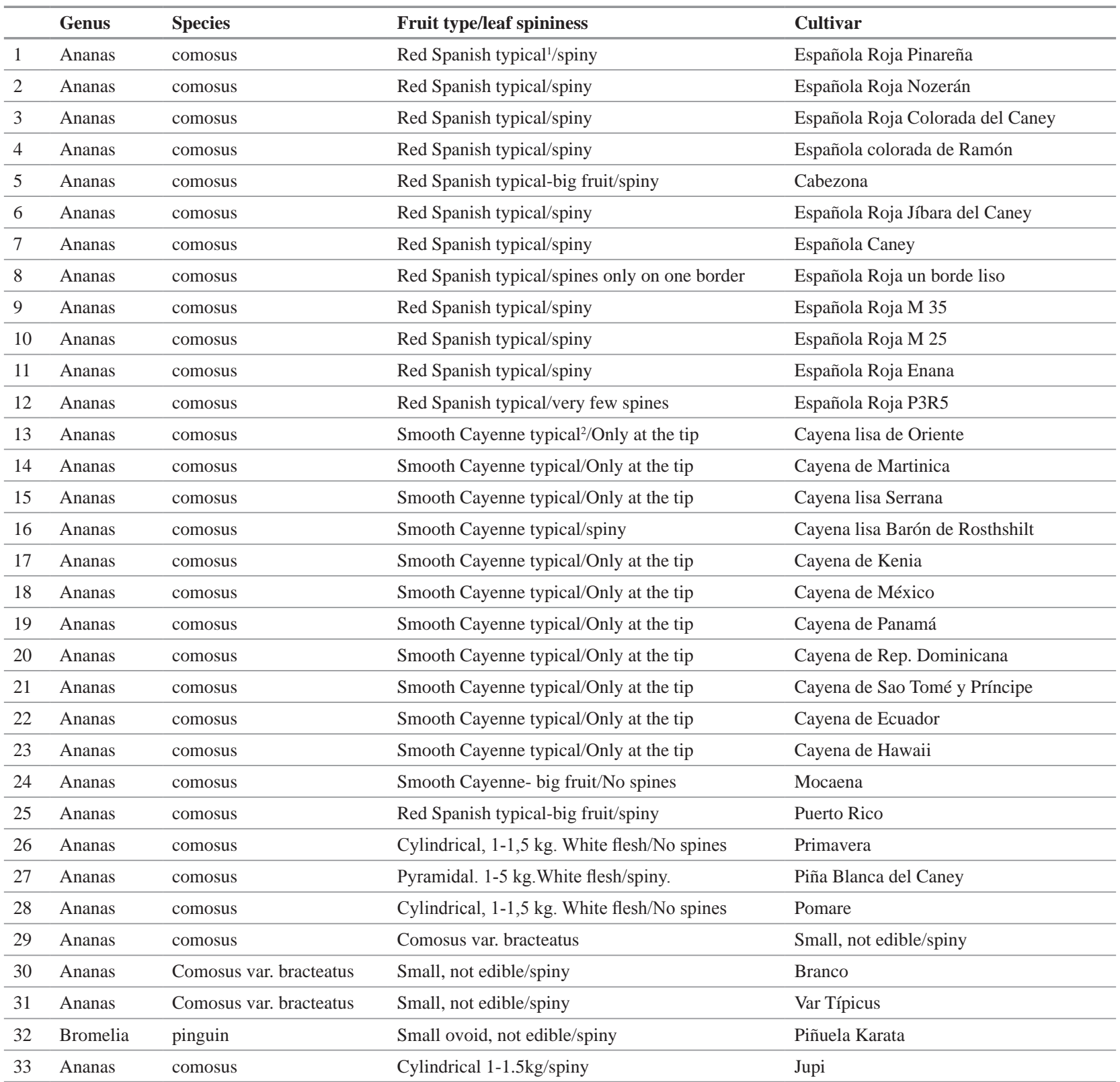


Genetic diversity of Cuban pineapple germplasm assessed by AFLP Markers

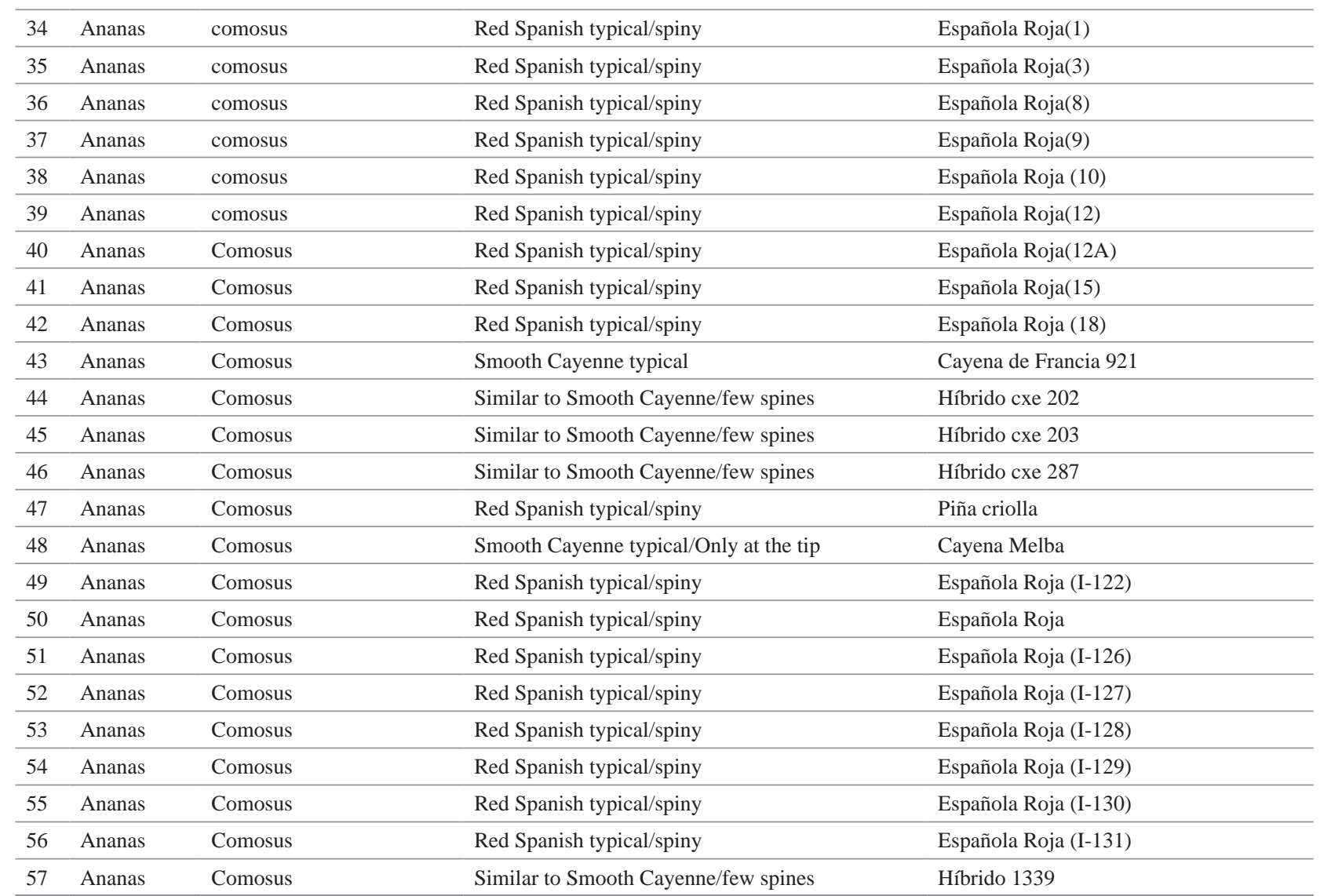

${ }^{1}$ Red Spanish Typical- fruit weight around $2 \mathrm{~kg}$, pale yellow flesh with pleasant aroma; squarish in shape. Well adapted for shipping as fresh fruit to distant markets. Spiny leaves. ${ }^{2}$ Smooth Cayenne typical- Fruit weight between $2.5-3 \mathrm{~kg}$, pale yellow to yellow flesh. Cylindrical in shape and with high sugar and acid content. Well adapted to canning and processing. Leaves with spines only at the tip.

Leaf samples were collected and stored at $-20{ }^{\circ} \mathrm{C}$ until DNA extraction. DNA isolation was based on the protocol described by Kobayashi et al. (1998) with several modifications. It was used $250 \mathrm{mg}$ of fresh young leaf tissue, which was grinded in liquid nitrogen and resuspended by vortexing in $650 \mu \mathrm{L}$ of extraction buffer $\left(50 \mathrm{mmol} \mathrm{L}^{-1}\right.$ Tris-Cl, pH 7.5, 20 mmol L-1 EDTA, pH 8.0, 0.3 mmol L $^{-1}$ $\mathrm{NaCl}, 2 \%$ sarcosyl, $0.5 \%$ SDS [Sodium Dodecyl Sulfate] and $\left.4.8 \mathrm{~mol} \mathrm{~L}^{-1} \mathrm{urea}\right)$. Then, an equal volume $(650 \mu \mathrm{L})$ of phenol-chloroform-isoamilic alcohol (25:24:1, v:v:v) was added. After centrifugation at $12000 \mathrm{rpm}$ for $15 \mathrm{~min}$, at room temperature in a tabletop centrifuge, the DNA in the liquid phase was precipitated by adding 0.8 volume of isopropanol at room temperature and centrifuging for 10 min at $12000 \mathrm{rpm}$. The pellet was then washed with $70 \%$ ethanol and the DNA was resuspended in $50 \mu \mathrm{L}$ of DNAase water free, containing $10 \mu \mathrm{g} \mathrm{mL}^{-1}$ of Rnase A. The quality and integrity of DNA was checked in a $0.8 \%$ agarose gel. DNA concentration was visually estimated by using a series DNA of standards.
AFLP analysis was carried out according to Vos et al. (1995). The EcoRI+A(5'-AGACTGCGTACCAATTC/A-3'), and the MseI+A (5'-GACGATGAGTCCTGAGTAA/A-3') oligonucleotide primers were used for the preamplification step. This step was followed by a second selective amplification step using three selective nucleotides. The EcoRI primer was kept constant with the selective nucleotides AAT whereas the Mse I primer varied with addition of an extra AG, TG, GT or CC.

Autoradiograms were analyzed visually and scored as $1=$ presence of band, $0=$ absence of band. Genetic similarity was calculated using the NTSYS-pc software (Rolf 2000) using the simple matching coefficient (SMC) (Skroch et al. 1992). Given two samples $i$ and $j$, SMC is the sum of the number of AFLP bands that are present in both samples plus the number of AFLP bands absent in both samples, divided by the total number of possible bands in the study. This coefficient varies between $0-1$. Genetic distances were calculated using the formula: Distance=1-SMC. Cluster analysis was based on distance 
matrices using the unweighted pair group method with arithmetic averages (UPGMA) and relationships between samples were graphically presented as dendrograms.

\section{RESULTS AND DISCUSSION}

A total of 191 scorable AFLP bands were generated with four primer combinations (Table 2). The levels of polymorphism of the collection were: $87.4 \%$ polymorphism considering both the genera Ananas and Bromelia, and 64.3 $\%$ considering only Ananas comosus. The use of the four primer combinations allowed differentiating all genotypes one another. Indeed, it was possible to differentiate the somaclones from Española Roja pinareña M-35 and P3R5 obtained by Pérez (2008). These somaclones were also differentiated previously by Pérez et al. (2008) using AFLP.

In this study the average number of bands per primer combination was 44.6. The number of bands per enzyme/ probe combination informed by Duval et al. (2001) using RFLP markers was 7.9. Tapia et al. (2005) obtained 5.9 bands per primer combination using ISSR markers and 6.83, using RAPD markers. Bejaj et al. (2003) compared RAPDs, AFLPs and SSRs in terms of their informativeness and efficiency in a study of genetic diversity and relationships among 32 olive cultivars grown in Italy and Spain. SSRs presented a higher level of polymorphism and greater information content, as assessed by the expected heterozygosity, than AFLPs and RAPDs.

The highest genetic distance (0.58) was found between Bromelia pinguin and the rest of the accessions. All Ananas comosus accessions were grouped at distances lower than 0.20 . Two main clusters can be identified in the dendogram (Figure 1), one includes Red Spanish genotypes and hybrids from Red Spanish and Cayenne and the other consists mainly of Smooth Cayenne genotypes. According to Isidrón et al. (2003), the Red Spanish accessions are the most cultivated in Cuba. They are barrel-like fruits, with spiny leafs and are very well adapted to the Cuban climate conditions. On the other hand, Smooth Cayenne genotypes are characterized by their cylindrical fruits and leaves with spines only at the tip. They are less adapted to Cuban climate conditions and more susceptible to soil diseases (Isidrón et al. 2004). Similarly, there are some other small genotypes clusters, including other less related cultivars. Although a similar study has not been done with morphological markers, the partial characterization carried out with this kind of markers, the results obtained with isozyme markers and the data obtained from curators allow us to make some comparisons with the molecular analysis.

The levels of polymorphism detected in the present study were acceptable taking into consideration the low genetic diversity of the collection. Paz et al. (2005), using AFLP markers, obtained $98.2 \%$ of polymorphism on 39 genotypes of the Mexican pineapple germplasm collection. This is superior to the $87.4 \%$ obtained by the Cuban collection. However, the Mexican collection includes three genotypes of Bromelia (two more than the Cuban). On the other hand, Duval et al. (2001), using RFLP markers, found $94.4 \%$ polymorphism among 294 accessions belonging to five Ananas species, and $74.7 \%$ among 167 accessions of Ananas comosus (according to the classification by Smith and Downs [1979]). However these results are not directly comparable to this work since here a much narrower collection of germplasm was analyzed. Another work was done in pineapple using isozyme markers (De Wald et al. 1992) but its scope is very limited due to the low level of polymorphism and the number of loci being identified. The levels of polymorphism are in close relation with the species and the number of genotypes being evaluated. For instance, using AFLP markers Tang et al. (2003) obtained $88.5 \%$ polymorphism among 125 genotypes of Hibiscus tileaceus, while Zong et al. (2003) reached only 55 \% polymorphism among 156 accessions of Vigna angularis.

The AFLP technique allowed to separate clearly the wild species Bromelia pinguin and Ananas genotypes from the rest of the genotypes of that genus. Likewise, almost all Red Spanish genotypes were separated from Cayenne's genotypes. Among Red Spanish genotypes some data support the robustness of the molecular analysis. For instance, Española M-35 is a somaclone of Española Roja Pinareña,

Table 2. AFLP Primer combinations, number of markers and levels of polymorphism

\begin{tabular}{lccccc}
\hline Primer combination & Number of markers & $\begin{array}{c}\text { Total number of poly- } \\
\text { morphic markers }\end{array}$ & Polymorphism (\%) & $\begin{array}{c}\text { Number of poly- } \\
\text { morphic markers in } \\
\text { Ananas }\end{array}$ & Polymorphism (\%) \\
\hline Eco-AAT, Mse-AAG & 46 & 36 & 78.2 & 17 & 37.0 \\
\hline Eco-AAT, Mse AAC & 43 & 37 & 86.0 & 29 & 40 \\
\hline Eco-AAT, Mse-AGT & 50 & 46 & 92.0 & 37 & 80.0 \\
\hline Eco-AAT, Mse ATG & 52 & 48 & 92.3 & 123 \\
\hline Total & 191 & 167 & 87.4 & & 71.1 \\
\hline
\end{tabular}




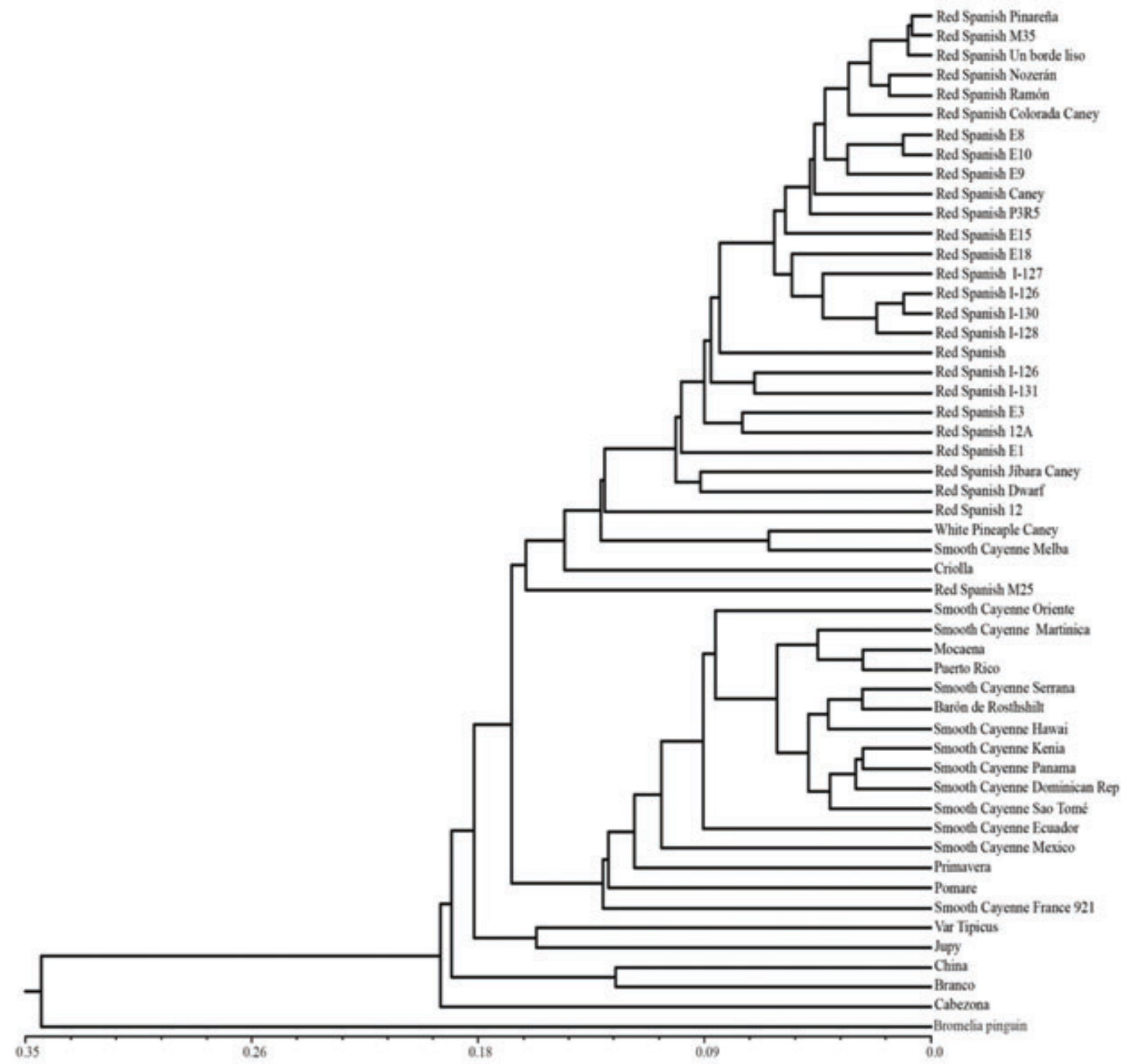

Figure 1. Dendrogram showing the diversity of the Cuban pineapple germplasm collection. Accessions are presented with cultivar names.

which is morphologically very similar to it; both genotypes are located very close to each other in the dendogram. The other somaclone of Española Roja Pinareña (Española Roja P3R5), with certain morphological differences, such as the absent of spines on the leaf margins and a different agronomical behavior (Pérez 2008), is located more distant from it in the dendogram, but as a member of a little cluster that includes Española Roja Pinareña.

Española Roja (8), Española Roja (9) and Española Roja (10) are morphologically very similar and were collected in the same region and are grouped in a small cluster at dis- tances less than 0.05 . Also, a group of genotypes collected in La Isla de la Juventud (Española Roja (I-127), Española Roja (I-126) Española Roja (I-130) Española Roja (I-128), Española Roja (I-129) and Española Roja (I-131) are clustered together at a distance less than 0.08 .

The Hybrids (CxE) 203 and (CxE) 287 were located in an intermediate position between Cayenne and Red Spanish genotypes, in the second cluster, in which its male progenitor (Española Roja pinareña) is included. However, the hybrid (CxE) 1339, with its female progenitor Cayena lisa Serrana, grouped with the Cayennes' cluster. 
The Spanish genotypes are the most cultivated in Cuba, which, taking into account the grouping of these genotypes in the dendogram, permits to state that the genetic diversity of the cultivated pineapple in Cuba is very low. Most of the other genotypes present in the collection are not cultivated in Cuba.

Although AFLP is a very efficient technique, the molecular analysis randomly explores a number of loci and compares them, but an important part is unexplored. There could be some differences in this unexplored part of the genome, which could be in a locus of agronomical importance. Therefore, it is important to complement the molecular analysis with morphological data.

The information presented here could serve as the basis for the organization and development of the Cuban pineapple germplasm collection. For the collection to be more representa- tive of the broad spectrum of pineapple germplasm, it should be enriched with more cultivated and non-cultivated varieties since most of genotypes in this collection are Red Spanish or Cayenne's cultivars. Other collections previously characterized with morphological descriptors (Leal et al. 1986, Ferreira and Cabral 1993, Duval et al. 1996), such as those from Brazil, Martinique and Hawaii or with molecular markers such as the Brazilian (Duval et al. 2001) and the Hawaiian collections (Kato et al. 2004) showed more diversity.

\section{ACKNOWLEDGMENTS}

We want to acknowledge the International Foundation for Science (IFS), CONACyT (Mexico) and InWEnt (Germany) for supplying the funds for this research.

\section{Diversidade genética do germoplasma cubano de abacaxi avaliada por marcadores AFLP}

Resumo - A coleção cubana de abacaxi representa a diversidade genética de abacaxis cultivados no país e inclui importantes genótipos das coleções do Brasil e da Martinica. A coleção foi previamente caracterizada com descritores morfológicos, faltando ainda a sua caracterização molecular. Com este objetivo foram analisados 56 genótipos de Ananas comosus e um de Bromelia pinguin com 191 marcadores AFLP. O dendograma baseado nos resultados do AFLP e que representa as relações genéticas entre esses genótipos revelou baixa diversidade genética da coleção cubana de abacaxi. Todos os genótipos de Ananas comosus, as quais foram obtidos de agricultores das diversas regiões de Cuba, foram agrupados em distâncias menores de 0.20. Observou-se que a caracterização molecular da coleção está de acordo com a classificação morfológica feita previamente. O resultado é útil para os propósitos de melhoramento e conservação.

Palavras-chave: marcadores moleculares, acessos, Ananás.

\section{REFERENCES}

Aradhya M, Zee F and Manshardt RM (1994) Isozyme variation in cultivated and wild pineapple. Euphytica 79: 87-99.

Bejaj A, Satovic Z, Cipriani G, Baldoni L, Testolin R, Rallo and Trujillo I (2003) Comparative study of the discriminating capacity of RAPD, AFLP and SSR markers and of their effectiveness in establishing genetic relationships in olive. Theoretical and Applied Genetics 107: 736-44.

Breyne P, Rombaut D, Van Gysel A, Van Montagu M and Gerats T (1999) AFLP analysis of genetic diversity within and between Arabidopsis thaliana ecotypes. Molecular and General Genetics 261: 627-634.

Carlier JD, Reis A, Duval MF, Coppens d'Eeckenbrugge G and Leitao JM (2004) Genetic maps of RAPD, AFLP and ISSR markers in Ananas bracteatus and $A$. comosus using the pseudo-testcross strategy. Plant Breeding 123: 186-192.

Coppens d'Eeckenbrugge G and Leal F (2002) Morphology, anatomy and aaxonomy. In Bartholomew DP, Paull RE and Rohrbach C K (eds) The pineapple: botany, production and uses. CABI, Wallingford, 320p.
Coulibaly I, Revol B, Noirot M, Poncet V, Lorieux M, Carasco-Lacombe C, Minier J, Dufour M and Hamon P (2003) AFLP and SSR polymorphism in a Coffea interspecific backcross progeny (C.heterocalyx x $C$. canephora) x C. canephora. Theoretical and Applied Genetics 107: 1148-1155.

De Wald MG, Moore GA and Sherman WB (1992) Isozymes in Ananas (pineapple): Genetics and usefulness in Taxonomy. Journal of American Society of Horticultural Science 117: 491-496.

Duval MF, Buso GS, Ferreira FR, Noyer JL, Coppens d'Eeckenbrugge G, Hamon P and Ferreira ME (2003) Relationships in Ananas and other related genera using chloroplast DNA restriction site variation. Genome 46: 990-1004.

Duval MF, Coppens d'Eeckenbrugge G, Ferreira F, Cabral J and Bianchetti B (1996) First results from joint EMBRAPA - CIRAD Ananas germplasm collecting in Brazil and French Guyana. Acta Horticulturae 425: 137-144

Duval MF, Noyer JL, Perrier X, Coppens d'Eeckenbrugge G and Hamon P (2001) Molecular diversity in pineapple assessed by RFLP markers. Theoretical and Applied Genetics 102: 83-90. 
Duval MF and Coppens d'Eeckenbrugge G (1993) Genetic variability in the genus Ananas. Acta Horticulturae 334: 27-32.

Ferreira F and Cabral J (1993) Pineapple germplasm in Brazil. Acta Horticulturae 334: 23-26.

Isidrón M, Rosales Y, Pifferrer A, Cisneros A, Benega R and Carvajal C (2003) Caracterización del germoplasma de piña colectado en cuba mediante prospección nacional: I. Localización, diversidad genética y situación actual. Cultivos Tropicales 24: 65-71.

Kato CY, Nagai C, Moore PH, Zee F, Kim MS, Steiger DL and Ming $\mathrm{R}$ (2004) Intra-specific DNA polymorphism in pineapple (Ananas comosus (L.) Merr.) assessed by AFLP markers. Genetic Resources and Crop Evolution 51: 815-825.

Kobayashi N, Horikish T, Katsuyama H, Handa T and Takayanagi K (1998) A simple and efficient DNA extraction method for plants, especially woody plants. Plant Tissue Culture and Biotechnology 4: 760-780.

Leal F, García ML and Cabot C (1986) Prospección y recolección de Ananas y sus congéneres en Venezuela. Plant Genetic Resources Newsletter 66: 16-19.

Marulanda ML, López AM and Aguilar SB (2007) Genetic diversity of wild and cultivated Rubus species in Colombia using AFLP and SSR markers. Crop Breeding and Applied Biotechnology 7: 242-252.

Paz EY, Gil K, Rebolledo L, Rebolledo A, Uriza D, Martínez O, Isidrón M and Simpson J (2005) AFLP characterization of the Mexican pineapple germplasm collection. Journal of the American Society of Horticultural Science 130: 575-579.

Pérez G, Yanes E, Isidrón M and Lorenzo JC (2008) Phenotypic and AFLP characterization of two new pineapple somaclones derived from in vitro culture. Plant Cell Tissue Organ Culture 96: 113-116.
Rohlf FJ (2000) NTSYS-pc: Numerical taxonomy and multivariate analysis system, version 2.1. Exeter Software, New York, 38p.

Santos CAF, Drumond MA, Rodrigues MA and Evangelista MRV (2010) Genetic similarity of Jatropha curcas accessions based on AFLP markers. Crop Breeding and Applied Biotechnology 10: 364-369.

Skroch P, Tivang J and Nienhaus J (1992) Analysis of genetic relationships using RAPD marker data. In Applications of RAPD technology to plant breeding. Joint Plant Breeding Symposia Series. Madison, p. 40-50.

Smith LB and Downs RJ (1979) Bromelioidees (Bromeliaceae). Flora Neotrópica 14: 2142.

Tang T, Zhong Y, Jian S and Shi S (2003) Genetic diversity of Hibiscus tiliaceus (Malvaceae) in China assessed using AFLP markers. Annals of Botany 92: 409-14.

Tapia Campos E, Guillén Andrade H and Gutiérrez Espinosa MA (2005) Caracterización genética de materiales de piña (Ananas spp.) mediante RAPD e ISSR. Revista Fitotecnia Mexicana 28: 187-194.

Tapia Campos E, Guillén AH, Gutiérrez EMA, Warbourton LM, Uriza AD and Rebolledo MA (2005) In Rebolledo Martinez A (ed.) Characterization of pineapple germplasm (Ananas spp) by mean AFLPs Proceedings of $4^{\text {th }}$ IS on pineapple. Acta Horticulturae 666.

Vos P, Hogers R, Bleeker M, Reijans M, Van de Lee T, Hornes M, Fritjters A, Pot J, Peleman J, Kuiper M and Zabeau M (1995) AFLP: A new technique for DNA fingerprinting. Nucleic Acids Research 23: $4407-4414$.

Zong XX, Kaga A, Tomooka N, Wang XW, Han OK and Vaughan D (2003) The genetic diversity of the Vigna angularis complex in Asia. Genome 46: 647-58. 